\title{
Review Article: ISTR, a Retrotransposons-Based Marker to Assess Plant Genome Variability with Special Emphasis in the Genera Zea and Agave
}

\author{
Martha Isabel Torres-Morán ${ }^{1 *}$, Norma Almaraz-Abarca ${ }^{2}$, Martha Escoto-Delgadillo ${ }^{1}$ \\ ${ }^{1}$ Centro Universitario de Ciencias Biológicas y Agropecuarias, Universidad de Guadalajara, Guadalajara, México; ${ }^{2}$ Centro Interdisci- \\ plinario de Investigación para el Desarrollo Integral Regional, Instituto Politécnico Nacional, Unidad Durango, Durango, México. \\ Email: ${ }^{*}$ isabel.torres@cucba.udg.mx
}

Received September $16^{\text {th }}, 2012$; revised November $18^{\text {th }}, 2012$; accepted November $26^{\text {th }}, 2012$

\begin{abstract}
A review is presented for give information and highlights the advantage of ISTR as molecular marker which with the genome changes after manipulation or breeding intervention can be detected.
\end{abstract}

Keywords: Transposable Elements; Zea mays; Agave tequilana; Agave durangensis; Molecular Markers

\section{Introduction}

At present time, humanity is able to understand many facts about genomes. Information is available from many points of view and everyone has the right to be informed about different aspects of genetic manipulation regard organisms. The well-being of humanity depends on how countries manage their resources, specially the alimentary ones. Plant breeding plays an important role in alimentary security and sustainable methods for producing crops and transforming wild species into cultivated plants. Plant breeding can be defined as a complex of techniques which has the aim to improve the quality, diversity and performance of agricultural and horticultural crops [1]. Plant breeding implies genetic manipulation since each plant contains many of thousand of genes and breeders wants to combine several traits in one plant. By other hand, plant genome can be changed under the press of many factors that includes men's hand or just the environmental action. Genetic changes can appear after the different processes plants suffer. The change magnitudes depend mostly on the propagation type used and also can occur naturally. Those changes must be assessed. Regarding sexual propagation, the need of conserving germplasm for future generations seems to be one of the principal reasons for build sustainable productions and it is important to verify the genetic fidelity during the presservation of germplasm collections for multiple purposes $[2,3]$. Asexual propagation produces other routes of genetic changes; regulated also by epigenetic mechanisms

${ }^{*}$ Corresponding author.
[4] that produces evident changes in phenotype. The general aspects of genetic variation can be described from the main patterns in which they evolved as described by: mutation, recombination, selection, isolation and drift [5]. Besides, there are thousands of reports of genetic changes after modern techniques of biotechnology and breeding in many crops. At this time, transformation and transposon-induced changes are new ways of mutation [5-8]; transformation and somatic hybridization are new ways of recombination [9]. Techniques like embryo rescue and in vitro pollination have permitted hybridizations till now impossible [10,11]. Molecular data offer important information to understand and assess relationships between cultivated and wild plants, makes evident the differences among phenotypes and make visible the changes in gene sequences and the proteins that they encoded. The management and evaluation of large germplasm collections requires efficient tools to analyze accessions, and molecular characterization is often obligated for registering varieties [2,3]. This review pretends give information and highlights the advantage of ISTR as molecular marker which with the genome changes after manipulation or breeding intervention can be detected. Zea and Agave genera were chosen as examples of sexually and asexually propagated plants respectively.

\section{Retrotransposon Mechanism}

Retrotransposon is a kind of transposable elements which plays an important role in genome and gene evolution in plants. Transposable elements are segments of DNA with 
the ability to move between different sites in chromosome and they moves directly as DNA in a "copy and paste" or "cut and paste" fashion, whereas retrotransposons expand via reverse transcription of an mRNA intermediate transcribed from the mobile element $[12,13]$. Retrotransposons have been found in every type of organism, are ubiquitous, dynamic and abundant in eukaryotic genomes $[8,14]$. They are categorized into two large groups, long-terminal-repeat (LTR) and non-LTR retrotransposons also known as LINE elements, on the basis of their overall structures. Recent phylogenetic analyses based on theamino acid sequences of Pol proteins have demonstrated that each of these two groups is composed of several distinct clades, members of which are thought to be tightly related one another in evolutionary terms [15]. LTR retrotransposons are further divided, the two most important groups are Ty1 or copia, and Ty3 or gypsy. The major structural difference between copia and gypsy groups is in the order of the reverse transcriptase (RT) and integrase domains in their pol genes. Gypsy group elements have similarities to retroviruses. The RT genes have conserved amino acid domains, some of which are characteristic of each retroelement group $[12,15]$. The LTRs are the sequence repeats that flank the internal coding region which includes genes encoding both structural and enzymatic proteins. The genomic RNA that allows the specific movement of retrotransposon is transported to the cytoplasm, translated and bundled together with its gene products into a structure called a virus-like particle (VLP). The movement of a specific DNA fragment takes place when the gag gene (group antigen gene) encodes the protein that forms the virus-like particle inside which reverse transcription. The pol gene encondes enzymatic functions, including the protease that cleaves the Pol polyprotein, a reverse transcriptase that copies the retrotransposon's RNA into cDNA, and an integrase that integrates the cDNA into the genome [16].

Most retrotransposons are thought to be transcriptionally inactive [17] or silent in somatic tissues but active during certain stages of plant development and under the effect of stressful conditions [18]. The activity of retrotransposons can be induced by stresses and a consequence of increased retrotransposon mobility is the creation of new genetic variability that can be useful in stressful conditions [6]. This seems to be the most important thing for what restrotransposons-based markers could be a useful tool to detect changes in specific genes during breeding, or genetic manipulation of plants. This could give to breeders the chance to screening a priori the genome in study and detect specific changes and associate to the production or silencing of specific genes or genome regions.

\section{ISTR as a Tool to Assess Genome Changes in Maize}

The maize genome is plenty of retrotransposons. It was reported about 150,000 to 250,000 LTR-retrotransposons, about the $50 \%-80 \%$ of its genome. The broad distribution of retrotransposons in maize genome, could represent a convenient marker in some studies, due to the occasionally contribution to the plant fitness that is been namely "molecular domestication" of the element by the host genome [19]. The constant movement of retrotransposons can provide new regulatory properties to a gene [20], and the first step on detect that changes is to characterize the positions of retrotransposon-based sequences trough ISTR (Inverse Sequence-Tagged Repeats) [19]. ISTR are copia-like sequence-derived oligodeoxynucleotide primers used as molecular marker ubiquitously dispersed among eukaryotic genomes [21].

A comparison between the information given by microsatellites or simple sequence repeats (SSRs) and ISTR in maize were made in our laboratory. The objective was analyzes the genetic homogeneity in two lines of maize (LUG03 and CML282). The CML282 had two versions, the original and LUG282 generated by self-pollination in ten years of conserving it at germplasm bank of Universidad de Guadalajara [22]. Thirty individuals of maize lines were analyzed using both markers. Ten primers of SSRs, one for each chromosome of maize and two combination of ISTR were used. PCR was carrying out according to Matzuoka et al. [23] for SSRs and TorresMorán et al. [24] for ISTRs. Molecular weight matrix was obtained from SSR data and was calculated the genetic distances from a correlation matrix. For ISTRs a presence (1) abscense (0) matrix was made and calculated the Jaccard's coefficient of similarity. Results were showed in dendrograms based on UPGMA method.

Both markers were able to separate the lines in two principal groups and cluster together the two versions of CML282 (CML282 and LUG282). The results showed a high genetic fidelity among individuals for each line observed with SSRs (Figure 1). The polymorphism revealed with SSRs was $0.7 \%$. The similarity among individuals detected by ISTR was low that indicating that many regions of individual genomes were polymorphic (Figure 2).

Capability of ISTRs to detect differences among individuals of the same line, can allow breeders to detect specific genes using the procedure for elude specific bands and sequencing [25].

\section{Detecting Changes in Agave}

Agave tequilana Weber var. "azul" is an important plant for production of Tequila. This beverage actually known 


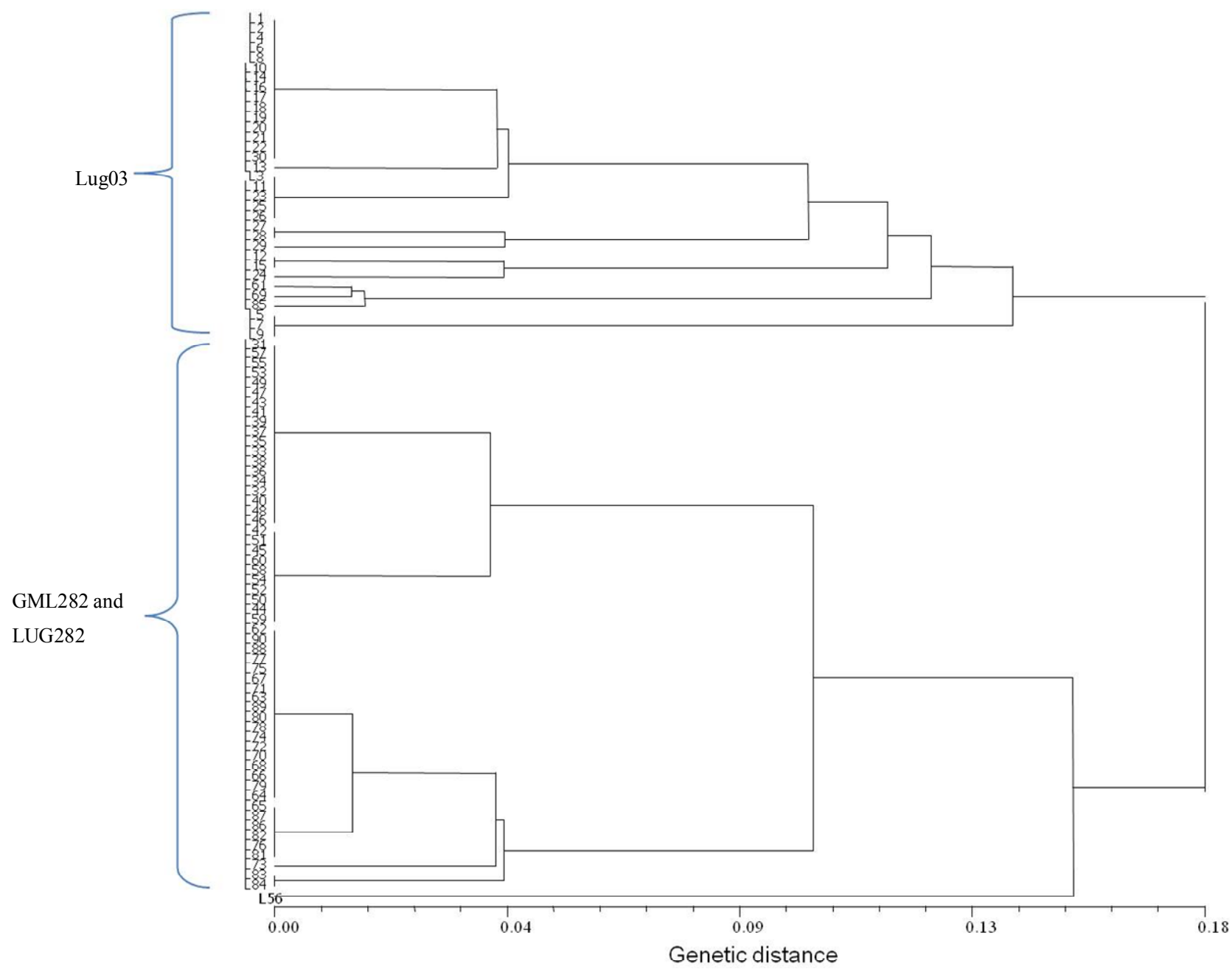

Figure 1. Dendrogram of the SSR analysis for three maize Lines.

all over the world generates a big gathering of resources due the importation of the product. There are several reports of genetic variability in this plant. Variation between initial agave explants and their micropropagated plants were detected. The differences between adult plants and off-shoots and among micropropagated plants [26-28] were detected, as well as the location of Ty1copia retrotransposons in the A. tequilana genome [29, 30]. The implications of detect such differences impacts the quality of tequila, because $A$. tequilana Weber var. "azul" (the blue agave) is the only one permitted to be used in elaboration of tequila.

Other species of Agave analyzed by our research group, using ISTR, was Agave durangensis. This species maintains a thriving mescal industry in Durango, Mexico. Contrary to the case of tequila and Agave tequilana, the mescal industry of Durango is mainly based on the gathering of agaves from their natural populations. Agave durangensis is a species of a restricted geographical distribution, and highly variable in size, color of leaf, size and form of teeth [31], and as was recently revealed, in the foliar phenol composition [32]; these last authors suggested that what has been named A. durangensis, actually could represent a complex of species instead of a single species.

The determination of the variability of populations and the parameters estimated to characterize them, like genetic distance, genetic identity, and genic flow, are important elements that contribute to establish the specific delimitation $[33,34]$. In our study, we estimated the above mentioned population parameters, using the ISTR markers, in order to determine the specificity status of three natural populations of $A$. durangensis, since ISTR has been recognized as markers having a high capacity to quantify genetic diversity and a high specific discriminatory capability $[21,24,35-37]$. The ISTR markers produced typical amplification profiles for each population of Agave durangensis, allowing distinguishing among them, which showed the capability of ISTR to discriminate among the natural populations of that taxon. High 


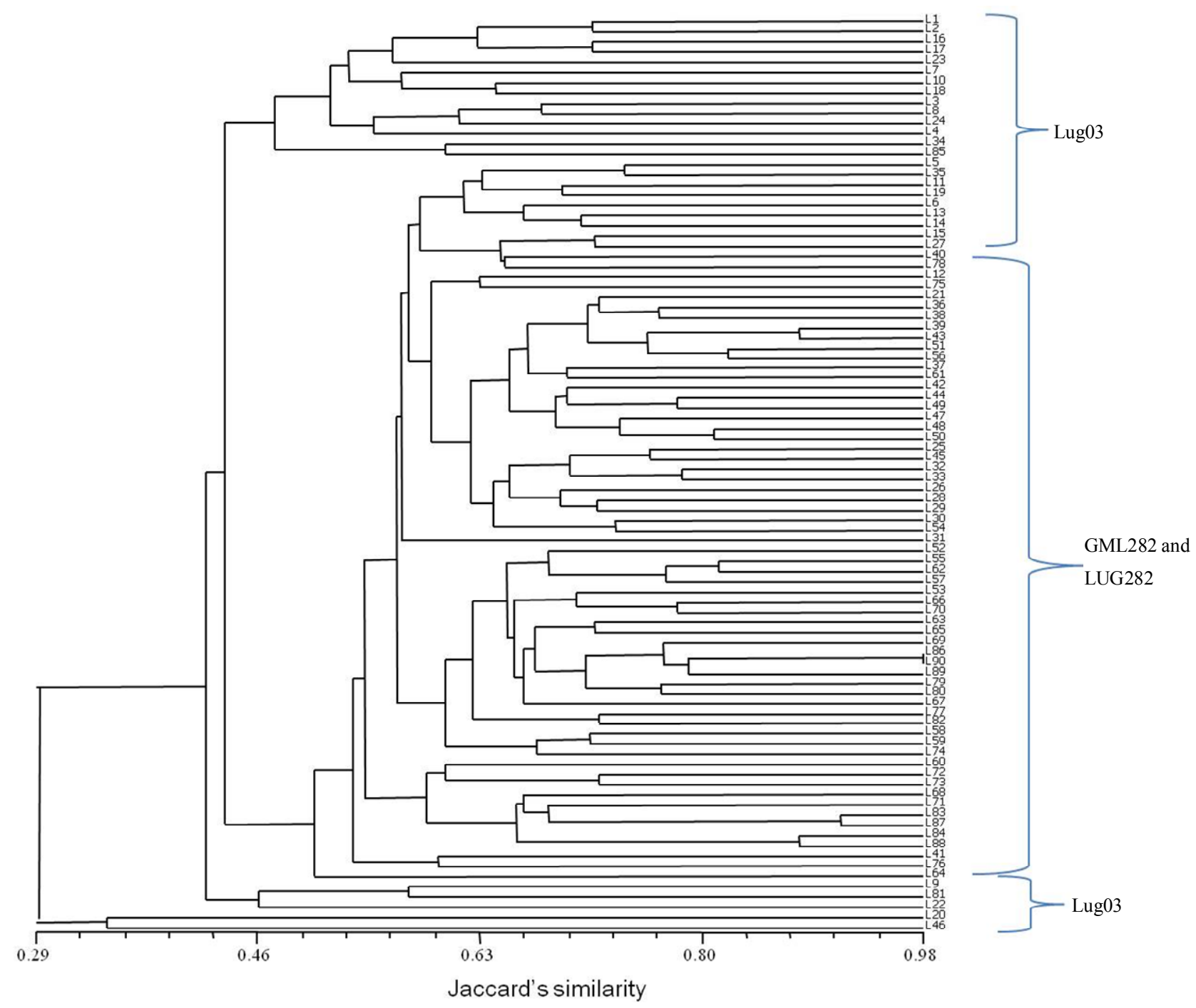

Figure 2. Dendrogram of the ISTR analysis for three maize Lines.

genetic variability was revealed by the ISTR markers, as was indicated by the elevated values of polymorphism (24.18\% to $61.50 \%$ ) among 91 loci amplified (varying in size from 61 to $12,412 \mathrm{pb})$, Shannon's diversity $(0.1208$ to 0.3435$)$, and gene diversity ( 0.0807 to 0.2337$)$, those values being similar to the average values reported by Hamrick and Godt [38] for widespread species. In our study, the number of markers generated by the ISTR, were reliable enough to estimate genetic distances in the populations evaluated, according to Keim et al. [39] who reported a number between 65 to 90 markers for precise surveys. The polymorphic information content (PIC) is used to measure the informativeness of a genetic marker [40], reaching as a maximum value of 0.5 for dominant markers [41], like the ISTR. The PIC values for the dominant ISTR markers used in the study of Agave durangensis varied between 0.22 and 0.42 , suggesting that those markers detected a high number of informative loci (contributing to variation).

The values of interpopulation gene differentiation (0.0328 to 0.4857$)$, gene flow (0.5294 to 14.7511$)$, genetic distance ( 0.0200 to 0.3019$)$, genetic identity $(0.7653$ to 0.9802 ), and the results of a cluster analysis suggested that one among the three populations of A. durangensis analyzed is in a present advanced diversification process but it may still maintain some level of genetic flow with the other two populations.

Genetic distance between populations is the extent of gen differences between populations or species [33]. A method of species delimitation based in this parameter assumes that reproductive isolation is the result of divergence across many loci scattered over the entire genome [42]. Groups differing by a Nei's genetic distance $\geq 0.15$ should be considered distinct species [34]. In our study 
of Agave durangensis, genetic distance $\geq 0.15$ were estimated from ISTR data, suggesting no conspecificity between some populations.

The ISTR markers proved to reveal variability within and among populations of Agave durangensis, suggesting that a particular ISTR profile can be associated to each one, and that each profile is the result of different integration events of new copies of retrotransposons accumulated in enough temporal and spatial separated entities. The amplification of ISTR patterns allowed differentiating between populations of $A$. durangensis. The ISTR fingerprinting allowed also clearly discriminating between the populations of $A$. durangensis and one population of Agave asperrima, the group used as reference, what is consistent with previous reports revealing the significance of the ISTR markers as valuable molecular tool at specific level in Agavaceae [24].

\section{Perspectives}

ISTR could be the initial step to detect genetic variability at specific level. This detection can allow to understand phenotypic and biochemical changes. This marker reveals also individual variations and discriminates between type or specific groups in Zea and Agave.

\section{Conclusion}

ISTR markers have been, in the last few years, matter of intensively studies. Nowadays, this research focuses in its applications to assess genetic variability, and to establish the specific limits and understand the taxonomic relationships of cultivated and wild species of plants. They have proven its utility when taxonomic controversies exist; the last application, having as well relevance in the determinations of diversity, because species are the basic unit of diversity. These molecular markers could be the first step to start breeding programs, based on reliable data.

\section{REFERENCES}

[1] BSPB, "Plant Breeding. The Business and Science of Crop Improvement," British Society of Plant Breeding, 2010. http://www.bspb.co.uk/BSPB\%20Handbook.pdf

[2] P. Escribano, M. A. Viruel and J. I. Hormaza, "Establishment of a Core Collection to Optimise the Conservation of Cherimoya (Annona cherimola Mill.) Genetic Resources Using ssr Information," Acta Horticulturae (ISHS), Vol. 814, 2009, pp. 67-70.

http://www.actahort.org/books/814/814_3.htm

[3] K. M. Evans, F. Fernández-Fernández and C. Govan, "Harmonising Fingerprinting Protocols to Allow Comparisons Between Germplasm Collections in Pyrus," Acta Horticulturae (ISHS), Vol. 814, 2009, pp. 103-106. http://www.actahort.org/books/814/814_10.htm

[4] C. Miguel and L. Marum, "An Epigenetic View of Plant Cells Cultured in Vitro: Somaclonal Variation and Beyond," Journal of Experimental Botany, Vol. 62, No. 11, 2011, pp. 1-13. doi:10.1093/jbx/err155

[5] W. Horn, "The Pattern of Evolution and Ornamental Plant Breeding," Acta Horticulturae (ISHS), Vol. 651, 2004, pp. 19-31. http://www.actahort.org/books/814/814_10.htm

[6] P. Capy, G. Gasperi, C. Biemont and C. Bazin, "Stress and Transposable Elements: Co-Evolution or Useful Parasites?" Heredity, Vol. 85, 2000, pp. 101-106. doi:10.1046/j.1365-2540.2000.00751.x

[7] J. L. Bennetzen, R. Liu, J. Ma and A. Pontaroli, "Maize Genome Structure and Rearrangement," Maydica, Vol. 50, 2005, pp. 387-392.

[8] V. C. Sarilar, A. Ridel, M. Rousselet, M. Falque, J-C. Tetanneur, F. Eber, A-M. Chévre, P. Brabant and K. Alix, "What Is the Impact of Allopolyploidy on Transposable Elements? A structural Approach on Newly Synthesized Brassica napus Allotetraploids," Acta Horticulturae (ISHS), Vol. 867, 2010, pp. 113-117.

[9] O. Omwoyo, J. V. Omondi-Muoma and J. Machuka, "Agrobacterium-Mediated Genetic Transformation of Selected Tropical Inbred and Hybrid Maize (Zea mays L.) Lines," Plant Cell Tissue and Organ Culture, 2012 (in press). doi:10.1007/s11240-012-0247-1

[10] W. Xiao, X. Huang, Q. Gong, X. Dai, J. Zhao. Y. Wei, and X. Huang, "Somatic Hybrids Obtained by Asymmetric Protoplast Fusion Between Musa Silk cv. Guoshanxiang (AAB) and Musa acuminate cv. Mas (AA)," Plant Cell Tissue and Organ Culture, Vol. 97, 2009, pp. 313-321. doi:10.1007/s11240-009-9530-1

[11] S. J. Ochatt, E. M. Patat-Ochatt and A. Moessner, "Ploidy Level Determination within the Context of in Vitro Breeding," Plant Cell Tissue and Organ Culture, Vol. 104, 2011, pp. 329-341. doi:10.1007/s11240-011-9918-6

[12] P. SanMiguel, A. Tikhonov, Y.-K. Jin, N. Motchoulskaia, D. Zakharov, A. Melake-Berhan, P. S. Springer, K. J. Edwards, M. Lee, Z. Avramova and J. L. Bennetzen, "Nested Retrotransposons in the Intergenic Regions of the Maize Genome," Science, Vol. 274, No. 5288, 1996, pp. 765-768. doi:10.1126/science.274.5288.765

[13] B. Young-An and Y. Kong, "Divergent Long-TerminalRepeat Retrotransposon Families in the Genome of Paragonimus westermani," Korean Journal of Parasitology, Vol. 41, No. 4, 2003. pp 221-223. doi: $10.3347 / \mathrm{kjp} .2003 .41 .4 .221$

[14] H. S. Malik and T. H. Eickbush, "Phylogenetic Analysis of Ribonuclease H Domains Suggests a Late, Chimeric Origin of LTR Retrotransposable Elements and Retroviruses," Genome Research, Vol. 11, 2001, pp. 1187-1197. doi:10.1101/gr.185101

[15] N. Friesen, A. Brandes and J. S. Heslop-Harrison, "Diversity, Origin, and Distribution of Retrotransposons (Gypsy and Copia) in Conifers," Molecular Biology and Evolution, Vol. 18, No. 7, 2001, pp. 1176-1188. doi:10.1093/oxfordjournals.molbev.a003905 
[16] E. R. Havecker, X. Gao and D. F. Voytas, "The Diversity of LTR Retrotransposons," Genome Biology, 2004, Vol. 5, p. 225. doi:10.1186/gb-2004-5-6-225

[17] A. Kumar and J. L. Bennetzen, "Plant Retrotransposons," Annual Review of Genetics, Vol. 33, 1999, pp. 479-532. doi:10.1146/annurev.genet.33.1.479

[18] M. A. Grandbastien, "Activation of Plant Retrotransposons under Stress Conditions," Trends in Plant Science, Vol. 3, No. 5, 1998 pp. 181-187. doi:10.1016/S1360-1385(98)01232-1

[19] P. SanMiguel, C. Vitte, J. L. Bennetzen and S. Hake, "The LTR-Retrotransposons in Maize," In: Handbook of Maize, Springer, New York, 2009, pp. 307-327.

[20] P. Bernet and M. J. Asíns, "Identification and Genomic Distribution of Gypsy-Like Rretrotransposons in Citrus and Poncirus," Theoretical and Applied Genetics, Vol. 108, No. 1, 2003, pp. 121-130. doi:10.1007/s00122-003-1382-1

[21] W. Rohde, "Inverse Sequence-Tagged Repeat (ISTR) Analysis, a Novel and Universal PCR-Based Technique for Genome Analysis in the Plant and Animal Kingdom," Journal of Genetics and Breeding, Vol. 50, No. 3, 1996, pp. 249-261.

[22] A. K. Rodríguez-Ponce, J. Ron-Parra, and M. I. TorresMorán, "Determinación Molecular de la Fidelidad Genética en dos Líneas de Maíz después de Ciclos de Autofecundación," Revista Internacional de Contaminación Ambiental, Vol. 28, No. 2, 2012, p. 146.

[23] Y. Matzuoka, S. E. Mitchell, S. Kresovich, M. Goodman and J. Doebley, "Microsatellites in Zea-Variability, Patterns of Mutations, and Use for Evolutionary Studies," Theoretical and Applied Genetics, Vol. 104, No. 2-3, 2002, pp.436-450. doi:10.1007/s001220100694

[24] M. I. Torres-Morán, N. Almaraz-Abarca, A. P. VelascoRamírez, V. Hernández-Vargas, G. Orea-Lara, A. CifuentesDíaz de León, and C. Oliver-Salvador, "Taxonomic Significance of ISTR to Discriminate Species in Agavaceae," American Journal of Agricultural and Biological Sciences, Vol. 3, 2008, pp. 661-665. doi:10.3844/ajabssp.2008.661.665

[25] J. Sambrook and D. W. Russell, "Molecular Cloning: A Laboratory Manual," 3rd Edition, Cold Spring Harbor Laboratory Press, New York, Vol. I, 2001.

[26] M. I. Torres-Morán, M. M. Morales-Rivera, L. De La Cruz-Larios and A. Villalobos, "Polymorphism Identification between Off-Shoots and Micropropagated Plants of Agave tequilana and Agave cocui Using ISTRs," Scientia-CUCBA, Vol. 8, 2006, pp. 203-206.

http://www.cucba.udg.mx/publicaciones1/page scientia cucba/scientia_cucba.htm

[27] M. I. Torres-Morán, M. Escoto-Delgadillo, S. MolinaMoret, D. M. Rivera-Rodríguez, A. P. Velasco-Ramírez, D. Infante and L. Portillo, "Assessment of Genetic Fidelity Among Agave tequilana Plants Propagated Asexually via Rhizomes versus in Vitro Culture," Plant Cell Tissue and Organ Culture, Vol. 103, No. 3, 2010, pp. 403-409. doi:10.1007/s11240-010-9777-6

[28] M. Díaz-Martínez, A. Nava-Cedillob, J. A. Guzmán-
López, R. Escobar-Guzmán and J. Simpson, "Polymorphism and Methylation Patterns in Agave tequilana Weber var. 'Azul' Plants Propagated Asexually by Three Different Methods," Plant Science, Vol. 185-186, 2012, pp. 321-330. doi:10.1016/j.plantsci.2012.01.004

[29] A. Bousios, I. Saldana-Oyarzabal, A. Valenzuela-Zapata, C. Wood and S. R. Pearce, "Isolation and Characterization of Ty1-Copia Retrotransposon Sequences in the Blue Agave (Agave tequilana Weber var. azul) and Their Development as SSAP Markers for Phylogenetics Analysis," Plant Science, Vol. 172, No. 2, 2007, pp. 291-298. doi:10.1016/j.plantsci.2006.09.002

[30] I. Khaliq, M. A. Khan and S. Pearce, "Ty1-Copia Retrotransposons Are Heterogeneous, Extremely High Copy Number and Are Major Players in the Genome Organization and Evolution of Agave tequilana," Genetic Resources and Crop Evolution, Vol. 59, No. 4, 2012, pp. 575-587. doi:10.1007/s10722-011-9705-6

[31] H. S. Gentry, "Agaves of Continental North America," The University of Arizona Press, Tucson, 1982.

[32] N. Almaraz-Abarca, A. Delgado-Alvarado, V. HernándezVargas, M. Ortega-Chávez, G. Orea-Lara, A. Cifuentes-Díaz de León, J. A. Ávila-Reyes and R. MuñizMartínez, "Profiling of Phenolic Compounds of Somatic and Reproductive Tissue of Agave durangensis Gentry (Agavaceae)," American Journal of Applied Science, Vol. 6, 2009, pp. 1076-1085. doi:10.3844/ajassp.2009.1076.1085

[33] M. Nei, "Estimation of Average Heterozygosity and Genetic Distance from a Small Numer of Individuals," Genetics, Vol. 89, No. 3, 1978, pp. 583-590.

[34] J. W. Sites and J. C. Marshall, "Operational Criteria for Delimiting Species," Annual Review of Ecology, Evolution, and Systematics, Vol. 35, 2004, pp. 199-227. doi:10.1146/annurev.ecolsys.35.112202.130128

[35] E. R. Sensi, W. Vignani, W. Rohde and S. Bricolti, "Characterization of Genetic Biodiversity with Vitis vinífera L. Sangiovese and Colorino Genotypes by AFLP and ISTR, DNA Marker Technology," Vitis, Vol. 35, 1996, pp. 183-188.

[36] J. R. Demey, E. Gamez, S. Molina and D. Infante, "Comparative Study of the Discriminating Capacity of AFLP and ISTR Markers for Genetic Analysis of Agave fourcroydes," Plant Molecular Biology Reporter, Vol. 22, No. 1, 2004, pp. 29-35. doi:10.1007/BF02773346

[37] M. J. Alonso, R. Cueto, Y. Santos, W. Romero, R. Llauger and W. Rohde, "Morphological and Molecular Variability of One Population of Green Coconut Plant in the Baracoa Region," Cultivos Tropicales, Vol. 28, 2007, pp. 69-75.

[38] J. L. Hamrick, and M. J. W. Godt, "Allozyme Diversity in Plant Species," In: H. D. Brown, M. T. Clegg, A. L. Kahler and B. S. Weir, Eds., Plant Population Genetics, Breeding, and Genetic Resource, Sinauer, Massachusetts, 1989, pp. 43-63.

[39] P. Keim, W. Beavis, J. Schupp and R. Freestone, "Evaluation of Soybean RFLP Marker Diversity in Adapted Germplasm," Theorical and Applied Genetics, 
Vol. 85, No. 2-3, pp. 205-212.

[40] X. Guo and R. C. Elston, "Linkage Information Content of Polymorphic Genetic Markers," Human Heredity, Vol. 49, No. 2, 1999, pp.112-118. doi:10.1159/000022855

[41] D. V. Sehgal, V. R. Rajpal, S. N. Raina, T. Sasanuma and T. Sasakuma, "Assaying Polymorphism at DNA Level for Genetic Diversity Diagnostics of the Safflower (Cartha- mus tinctorius L.) World Germoplasm Resources," Genetica, Vol. 135, No. 3, 2009, pp.457-470. doi:10.1007/s10709-008-9292-4

[42] R. Highton, "Taxonomic Treatment of Genetically Differentiated Populations," Herpetologica, Vol. 46, 1990, pp. 114-121. 